Article

\title{
Intertextuality and Mise en Abyme in Nobuhiro Suwa's H Story and A Perfect Couple. Between European Modernity and Japan
}

\author{
Miguel Muñoz-Garnica@ \\ Department of Audiovisual Culture and Communication, Universidad de Navarra, 31009 Pamplona, Spain; \\ mmunozg@alumni.unav.es
}

Received: 31 August 2018; Accepted: 25 September 2018; Published: 1 October 2018

\begin{abstract}
Nobuhiro Suwa, often called "the most French of Japanese directors", has a complex relationship with European cinematic modernity. His two feature films H Story (2001) and A Perfect Couple (2005) can provide useful case studies, as they were created in dialogue with two key references of that modernity: Hiroshima mon amour (1959, Alain Resnais) and Journey to Italy (Viaggio in Italia, 1954, Roberto Rossellini), respectively. Both films tend to confront and gloss their previous pairs, but they are also continuations of their concerns and their aesthetical discoveries. The presence of intertextuality elements connecting those films, as well as the use of myse en abyme structures are deeply analyzed in this article to attain a greater understanding on how this process of transcultural dialogue works. Besides, both films exemplify different ways of developing the references on which they are built, namely deconstruction for H Story and reconstruction for A Perfect Couple.
\end{abstract}

Keywords: contemporary Japanese cinema; cultural blending; intertextuality; mise en abyme; Nobuhiro Suwa; transculturality; (trans)national cinema

\section{Introduction. Nobuhiro Suwa and European Modernity}

"If modern cinema was already a post-cinema, what about cinema that watches and is inspired by it today?" asks Cahiers du cinéma critic (Joyard 2001, p. 68) in the introduction to his article on H Story. This question may be the most appropriate one in addressing the work of Japanese director Nobuhiro Suwa, whose complex relationship with European cinematic modernity is at the same time one of quotation and gloss, of continuity and confrontation. As this article explores, his third and fourth features, H Story (2001) and A Perfect Couple (Un couple parfait, 2005), are constructed in dialogue with two key references of that modernity: Hiroshima mon amour (1959, Alain Resnais) and Journey to Italy (Viaggio in Italia, 1954, Roberto Rossellini), respectively. In a similar way, his most recent film, The Lion Sleeps Tonight (Le lion est mort ce soir, 2017), builds its main character by assimilating into the fiction the cinephilic echoes of the actor who plays him: the Nouvelle Vague icon Jean-Pierre-Léaud. Suwa tends to draw his films from the cinema he loves, and this relationship, far from being merely anecdotal, constitutes the creative basis on which he works.

Suwa himself admits that discovering classical Hollywood at the same time as the Nouvelle Vague while he was studying at Tokyo Zokei University was his "introduction to movie-making". Feeling "desperation" with regard to contemporary Japanese cinema, he developed his strong interest in "directors whose cultural origins are complex", his fascination with a Nouvelle Vague that he considered a continuation of Alfred Hitchcock as much as of Roberto Rossellini (Fraga 2018) ${ }^{1}$. Therefore,

1 All translations from French and Spanish are by the author unless otherwise noted. 
Suwa seems to be well aware of the transnational influences that have earned him the title of "the most French of Japanese directors", a perspective that was already applied to him on the basis of his first and second features, 2/Duo (2/dyuo, 1997) and M/Other (1999), fully produced in Japan but dealing with the staple topic of modern cinema in the sixties: the couple in crisis (Font 2012, p. 519).

To understand in which cultural discourse Suwa's images are rooted, it is important to clarify the concept of "European modernity". Quintana (2007, pp. 58-60), who frames the director as one of the main examples of the last decade's aesthetic migrations from European modernity to Asian cinema, includes in this concept the films that derive from the developments following the first wave of Italian Neorealism to the new cinemas of the sixties. He also summarizes its spirit in the ideas of three essential authors: André Bazin (2005, pp. 9-16) theories about the ontological capacity of cinema to capture the "ambiguity of reality"; Jacques Rivette (1955) Lettre sur Rossellini, in which, inspired by the release of Journey to Italy, the critic and subsequent filmmaker describes Rossellini's film as a new turning point in modern cinema due to his use of "suspended time" and centreless frames; and the concept of "image-time" coined by the French philosopher Gilles Deleuze (Deleuze 1989, pp. 34-43), who stated that the cinematic image created by modernity lost its condition of a piece connecting, among the other pieces, a unique action, perception or affection that signified the whole film: instead, every piece, or every "image-time", drew attention to itself and its own values. In the origin of these new ways of creating and experiencing the cinematic image is the awareness of brutality (caused by World War II, the concentration camps and the bombs in Hiroshima and Nagasaki) that led to the rejection of classical cinema's "illusion" and its industry's "alienation". Modern cinema was born, as Serge Daney (1983, p. 172) puts it, "in destroyed and traumatised post war Europe, on the ruins of annihilated and disqualified cinema, on the fundamental refusal of the fake, of mise en scène, of the stage" $\mathrm{e}^{\prime 2}$.

To return to Joyard's words, if cinematic modernity is characterized by an intentional and conscious reinterpretation of previous cinema, Suwa as a director who questions that modernity may well be part of post-post-cinema. Nouvelle Vague cinema, as the early works of Jean-Luc Godard perfectly exemplify, dialogued openly with the genre patterns of classical Hollywood, in a mixed relationship of admiration and critique. Suwa's cinema, as this article shows, likewise engages in a twofold exercise of imitation and dialogue as well with some key films of European modernity. Two concepts from semiotics are used to focus the analysis: intertextuality and mise en abyme.

Intertextuality is a concept that Genette (1997, pp. 1-2) defines as "the effective co-presence of two texts" in the form of quotation, plagiarism and allusion. Stam et al. (2005, p. 211), who study filmic intertextuality, add that "quotation can take the form of the insertion of classic clips into films", whereas "allusion can take the form of a verbal or visual evocation of another film, hopefully as an expressive means of commenting on the fictional world of the alluding film". Suwa's usual employment of quotation and allusion allows us to trace his dialogue with European modernity. However, there is a special kind of intertextuality that, in addition to this, also discloses how the Japanese filmmaker appropriates the aesthetic discoveries of modernity. Stam calls it intratextuality, "the process by which films refer to themselves through mirroring, microcosmic, and mise en abyme structures". Mise en abyme is a term coined by writer André Gide: "In a work of art, I rather like to find thus transposed, at the level of the characters, the subject of the work itself. Nothing sheds more light on the work or displays the proportions of the whole work more accurately". For a better explanation of the concept, Gide made "a comparison with the device from heraldry that involves putting a second representation of the original shield 'en abyme' within it" (Dällenbach 1989, p. 7). Intertextuality and mise en abyme are two common practices in a European modernity much more

2 Translated from French by Laurent Kretzschmar and Otie Wheeler, 2013. Retrieved from: http:/ /www.sergedaney.blogspot. com/2013/08/la-rampe-bis.html. 
concerned about the act of representation itself than the cinema that preceded it, as well as key practices in Suwa's films.

\section{Deconstruction: H Story}

Suwa's third feature-length production and the first to be filmed in Japan with French participation, $H$ Story is undoubtedly the film that best illustrates its maker's complex intertextual relationship with European cinematic modernism, in general, and one of its emblematic works, in particular: Hiroshima mon amour. Interestingly, both films were the product of transnational partnership projects. In its initial form, Hiroshima mon amour was to have been a documentary produced by the Japanese company and directed by Resnais, who had just screened his cinematic essay on the Holocaust, Night and fog (Nuit et brouillard, 1955), to notable acclaim. However, Resnais felt that he would merely repeat what he had done in Night and fog, and that no further documentary on the subject was required given those already made by Japanese filmmakers; so he commissioned a script from the writer Marguerite Duras, a fictional love story set against the backdrop of the bombs (Armes 1968, pp. 66-67). H Story grew from a partnership project about Hiroshima pitched to Suwa by the American filmmaker Robert Kramer. Both men had a stake in the story: Kramer's father had been an airman who flew in a US reconnaissance mission after the bombing and was struck almost completely dumb, rendered "practically autistic", by what he saw; while Suwa himself was born and raised in Hiroshima. Suwa described the proposed project as follows:

We had decided to film one another with two cameras, looking at one another and talking about Hiroshima. What struck me most was the distance between us: having been born in the US, he had a very clear view, he was able to envision a film about Hiroshima; whereas I, born in Hiroshima, had nothing to say. When he asked me, "You were born there, what do you have to say about Hiroshima?", I couldn't come up with an answer. I wanted to film the difference in our outlooks, our points of view [ . . ] what interested me was the "and" that I saw between Kramer and myself. (Tesson 2001, p. 70)

However, Kramer's death soon afterwards brought the project to a premature end. Suwa decided to develop the idea of conversation outlined above, where the role of interlocutor that was to have been played by Kramer would be taken by the film Hiroshima mon amour. Resnais had deployed strategies of mise en abyme in his film so as to address what Deleuze referred to as the "incommensurability" characteristic of the modern image as such: the impossibility that cuts might create rational connections between shots. In Deleuze's words, "The interval is set free, the interstice becomes irreducible and stands on its own" (Deleuze 1989, p. 277). Such incommensurability also emerges between the "internal" life of the film and the "external" reality of the bombing of Hiroshima: the horror of the real event is so awful as to lie beyond narration. Duras wrote her script on the premise that Hiroshima could not be addressed. The film draws on various levels of reality that move the mechanics of its own fiction into a play of meanings: Hiroshima features as a documentary image; as the diegetic frame to the love story between a French woman (called simple Elle [She]) and a Japanese man (Lui [Him]) which drives the plot; and as a fiction within his work of fiction: Elle is an actress playing a part in a film shoot about the bombing. This threefold interrelationship sets up a hall of mirrors effect which in turn highlights the incommensurable "cuts" between them.

Suwa saw the subject of $H$ Story in the same way as Duras had before him: the impossibility of speaking about Hiroshima (Tesson 2001, p. 71). Thus, Suwa's film replicates and amplifies the levels of mise en abyme in Hiroshima mon amour by referring directly to them. The surface story comprises the endeavor to remake Resnais's movie, which—at the same time-is part of its structure as a fiction. Without changing a single word, Suwa puts Duras's script to the test, knowing that the project is doomed to failure, and roots his film in the fake 'making of' sequences and the scenes shot with Béatrice Dalle and Hiroaki Umano (in the roles originally played by Emmanuelle Riva and Eiji Okada, Elle and Lui), to which he adds archive footage and a digression in the film's second half into the love affair that 
arises between Dalle and the Japanese writer Kou Machida, the main supporting actor in the remake. The levels of reality multiply in relation to Resnais's film: the story within a story is-in Hiroshima mon amour the making of another movie-in H Story, the making of Hiroshima mon amour itself. At the same time, however, the film within a film is split between the script written by Duras, which is quoted word for word, and the shots of Dalle and Umano which allude indirectly to the scenes shot by Resnais. There is only one explicit visual quotation after the film's opening sequence, in which Dalle and Umano re-play the first scene in Hiroshima mon amour. The final frame is a medium shot of the lovers in bed (Figure 1a), an image that fades to black, followed by a shout of "Cut" and the sound of the director giving his orders. The black screen brightens to a still image from Hiroshima mon amour in which Riva and Okada are seen in a similar pose to the figures in the previous frame (Figure 1b).

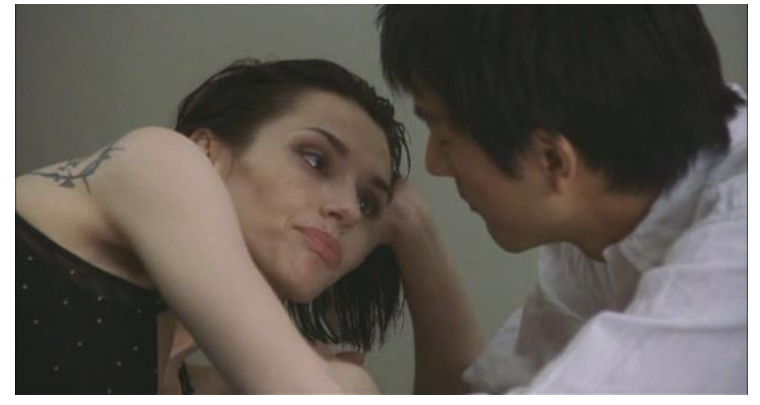

(a)

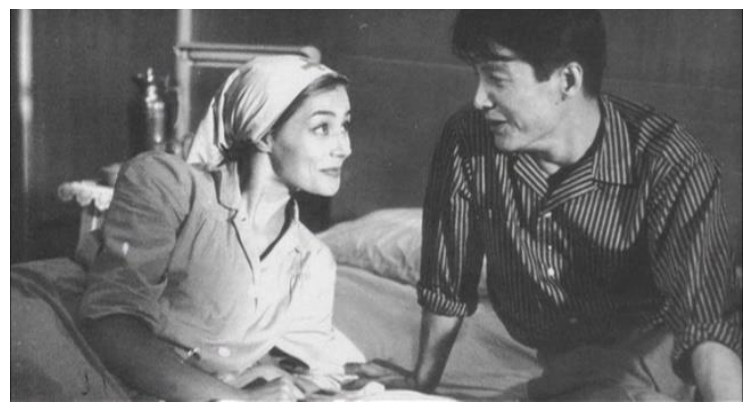

(b)

Figure 1. Frame (a) from H Story showing actors Béatrice Dalle and Hiroaki Umano representing a scene of Hiroshima mon amour, followed by a frame of the film (b) showing a photography of the original scene played by Emmanuelle Riva and Eiji Okada. Source: DVD edition by Cinéma Indépendant (France).

The depiction of both frames can even suggest a continuation between them, as Figure $1 \mathrm{~b}$ is a wider frame of the same disposition presented in Figure 1a. However, the differences on the actors and the nature of both images (film versus photography) evince that it is a false continuation. This can be read as the first mark of resistance that Suwa puts against Hiroshima mon amour. It is followed by a conversation segment between Suwa and Machida styled as part of the 'making of' depiction of the creative process. Thus, Resnais's film features as a deferred echo, a fixed (photographic) image that underscores the impossibility of the kind of mimesis proposed by the film's opening sequence. This split play of meanings redoubles as the film unfolds, since " $H$ Story is not an exact copy of Hiroshima mon amour, a tracing of it. Rather, it is one of the possible expressions produced by Hiroshima mon amour when the latter is apprehended as an abstract diagram, as an individuated entity which is built according to a principle of immanent multiplicity" (Hainge 2008, p. 166).

Thus, a range of meanings branch out from the "impossibility of talking about Hiroshima", which may be referred to as the "discourse of Hiroshima", as distinct from the "reality of Hiroshima". In its own time, Hiroshima mon amour was a film that endeavored to address the "epistemological crisis brought on by those events of the twentieth century which exceed comprehension" (Hainge 2008, p. 163); but over time, it has become an inescapable frame of reference for the "discourse of Hiroshima", despite Resnais's original refusal to undertake a documentary reconstruction of events: "While Hiroshima mon amour rejected the possibility of reconstruction, in its own time, [H Story] sets up, between itself and the world, the place of the other, the place in which an other is constructed in audiovisual terms, forcing the viewer to see and acknowledge, within this inter-filmic experience itself, the point-a point that he himself must determine-from which he views" (Grange 2011, pp. 180-81). What makes the point of view that Suwa obliges the viewer to take up such a slippery position is his use of Resnais's film both as the ground for his own work and as a framework that enables the proliferation of meaning. The first part of $H$ Story, from the very opening sequence outlined above, calls into question not merely the possibility of representing the horror of what happened in Hiroshima, but of representing a text which itself discusses that same impossibility. 
In contrast to the Suwa-character's determination to continue the shoot, Dalle embodies the growing crisis around the possibility of representation as such. In the opening scene, Dalle is able to recite her lines without fault or falter; later, the actress-character becomes more and more forgetful of Duras's script, before finally deciding that the effort to remember it is a stupid waste of time.

Dalle confirms what the referential images cited by Suwa have foreshadowed: the absurdity of his cinematic enterprise. So H Story ends up moving away from its early mix of mocked-up 'making of' and intertextualization to tell a new story by digressing from the earlier one. The shift in H Story is marked by the scene in which the crew try to film the meeting of Elle and Lui in a bar in Hiroshima mon amour. In Resnais's film, the scene blurred the temporal lines between the present time of the movie and Elle's reminiscences of her love affair with a German soldier during the Second World War. The shifts in time merge through a degree of sound continuity and Lui's performance of both his own self and the 'reincarnation' of the dead German soldier. A sentence spoken by Elle prefaces one of the flashbacks: "C'est horrible. Je commence à moins bien me souvenir de toi". This is the exact sentence that Dalle is unable to remember in the remake of the scene. Her inability to recall (to re-present) the expression of a memory undermines the temporal sleight of hand performed by Resnais. The shift in time is replaced by an act of flight. Dalle leaves the bar-that is, the space of memory in Hiroshima mon amour shaped by temporal discontinuity—and smokes outside the door with Machida, the writer, who until then had been only an observer of the film shoot.

Several intra-filmic elements set up these intertextual relationships. The river Ota, along whose bank Machida and Dalle stroll following the latter's flight from the bar (Figure 2c) is a vague vessel of meaning indicated verbally: in an earlier scene, Umano had told Dalle that many of the people of Hiroshima died having drunk contaminated water from the river after the bombing. In Hiroshima mon amour, the meanings associated with the river are broader. It appears just before the scene in the bar, when the viewer is presented with a sequence of shots showing the everyday life of ordinary people along the banks of the river (Figure 2a). However, it is also an ongoing feature of the background to the scene in the bar, through the window or the reflection of the lights on its waters that are reflected back inside. Moreover, in Elle's flashbacks during this scene, she recalls her encounters with the German soldier on the banks of the river Loire in Nevers (France), in such a way that the presence of the river prompts associations with the bar setting as well as with the world beyond it. The place is given the simple name "Tea Room Dōmu" in Hiroshima mon amour (Figure 2b), whereas in H Story no title appears until Dalle flees the set of the shoot and Machida goes after her, when the sign above the bar door takes on an ironic tone: under a sign saying "French-Japanese" (Figure 2d), two characters, the French woman Dalle and the Japanese man Machida, neither of whom speaks anything other than their own language, have a conversation. Suwa appropriates signs presented in Resnais's film so as to re-present them with new meanings. In the case of the river, the scene and setting it frames are the same, but a new meaning is generated through this approach to imitation.

Following this first failed attempt, Suwa sets out to re-shoot the same scene in the bar the next day. In an unscripted moment, Machida enters the scene at Suwa's request, in an apparent reprise of the role played by an unknown Japanese man who approaches Elle in one of the final scenes in Hiroshima mon amour. As in other scenes, the sound of a clapperboard marks the shift from the fake 'making of' to the re-make shoot of Hiroshima mon amour. The shot is held for around four minutes. Dalle is the first to enter the scene, emerging from the back of the frame. She sits at a table to the right and orders a drink, peering into the darkness of the setting around her until she sees a reddish light seeping in under the door at the back of the bar through which she had entered (Figure 3a). Umano comes through the same door and sits at a table farther away from the camera, near the center of the frame (Figure 3b). The two characters glance at one another, but they do not make full eye contact. Before they can make a real connection, Machida breaks into the scene, occupying the empty space at frame-left (Figure 3c), making his way towards Dalle's table, where he sits down and stares at her (Figure 3d). 


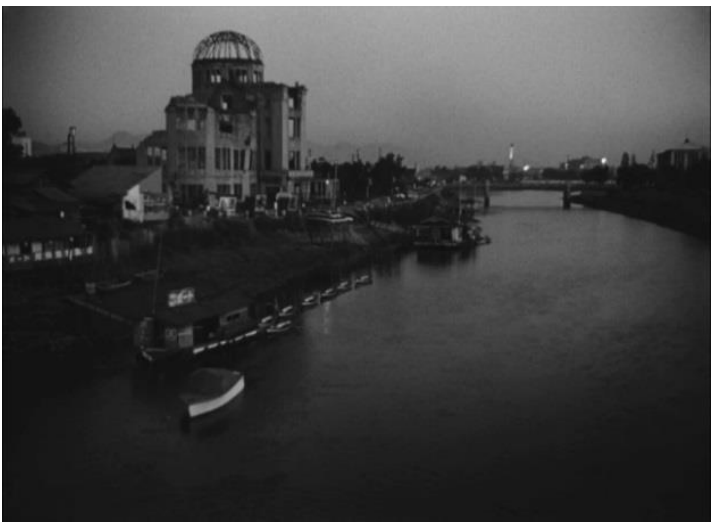

(a)

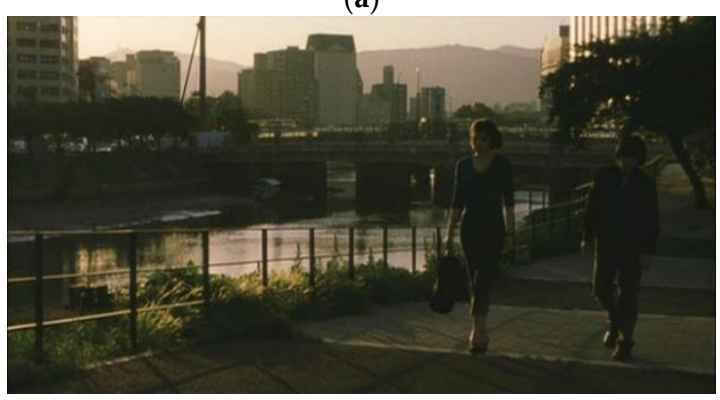

(c)

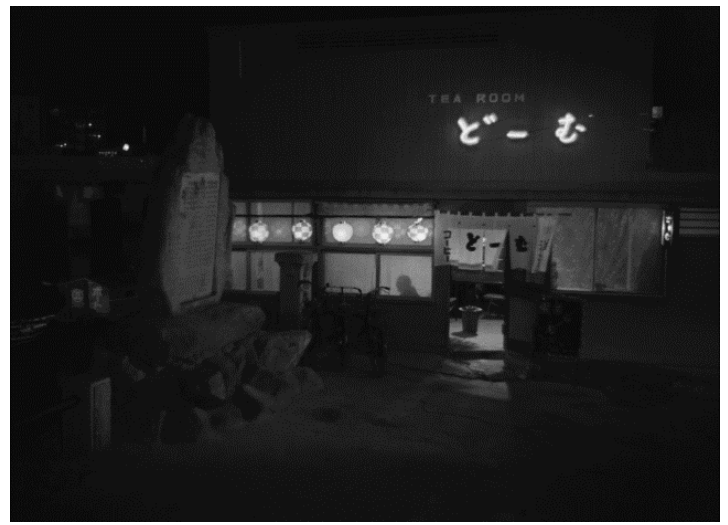

(b)

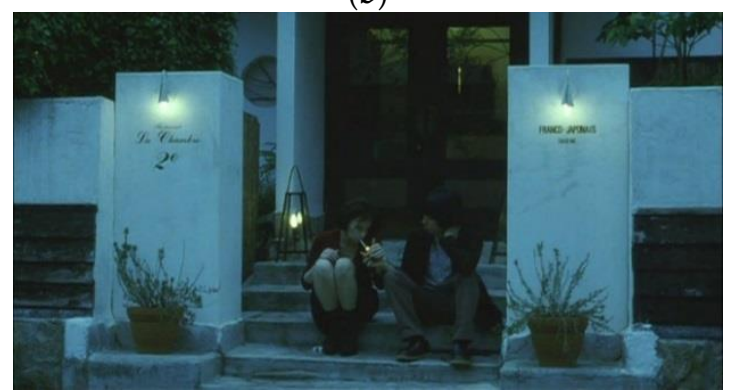

(d)

Figure 2. Frames showing similar sets in Hiroshima mon amour and H Story: the Ota River $(\mathbf{a}, \mathbf{c})$ and the restaurants $(\mathbf{b}, \mathbf{d})$ where a key scene takes place in both films. Source: DVD editions by Acontracorriente (Spain) and Cinéma Indépendant (France).

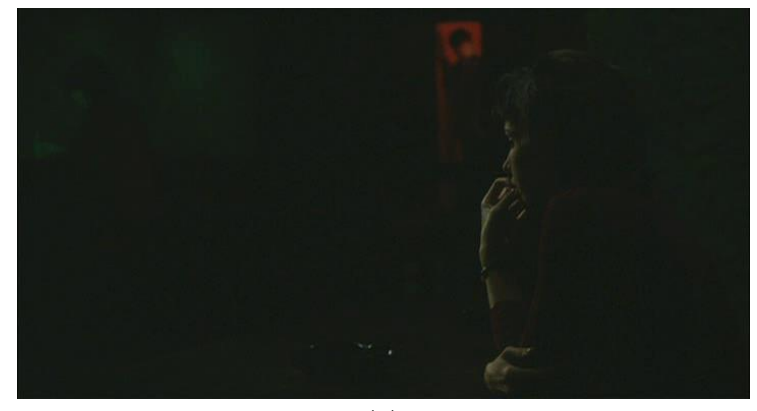

(a)

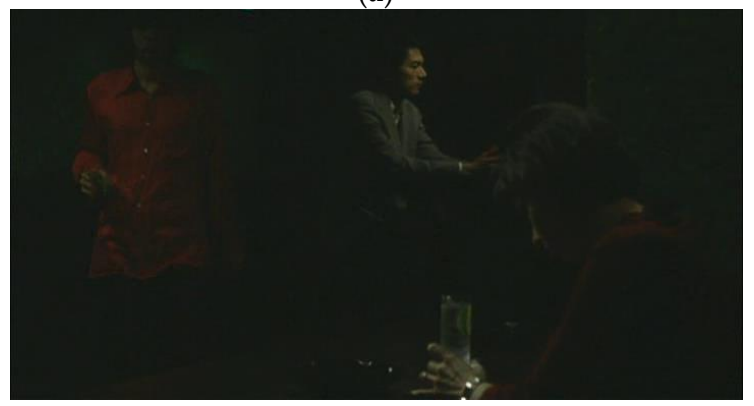

(c)

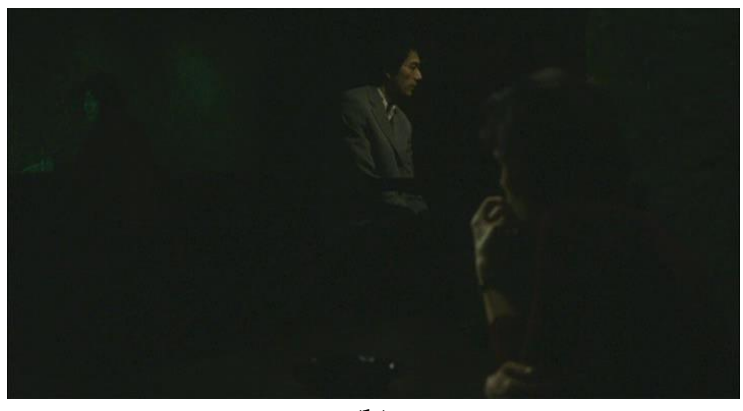

(b)

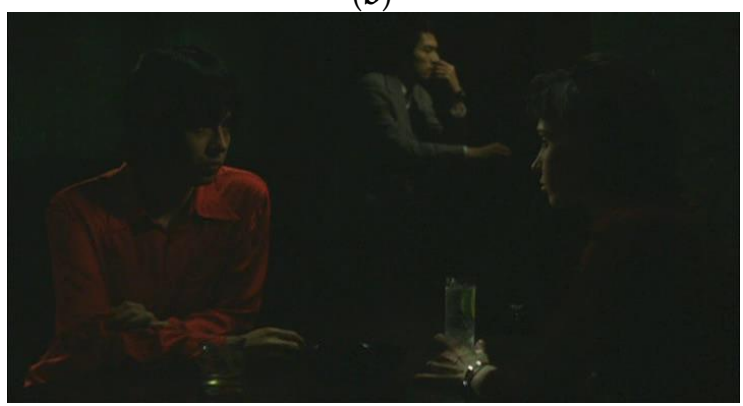

(d)

Figure 3. Four frames from $H$ Story taken of a unique static shot showing the entrance of actors Hiroaki Umano (a,b) and Kou Machida $(\mathbf{c}, \mathbf{d})$ changing the dynamic of attractions around the main character played by Béatrice Dalle (at the right of the images). Source: DVD edition by Cinéma Indépendant (France). 
Tracking the dynamic of his gaze, the camera turns slowly through $90^{\circ}$ on its axis, coming to rest on an almost face-on shot of Dalle, who is still looking at Machida. The camera movement and the play of colors (the reds of Machida's shirt and the weak light leaking in from outside disrupt the languid greens that have colored the scenes in the bar thus far) underscore the shifting attractions at the heart of the film: Machida, an accidental actor, a member of the cast of the mocked-up 'making of' not the remake, steals the scene by neutralizing the chemistry between Dalle and Umano, the supposedly lead romantic couple. What was to have been a re-shot scene from Hiroshima mon amour becomes a long wordless shot from which the story of H Story itself surfaces. Is the silence of the scene due to Dalle's failure to remember her lines? Why does Suwa not cut the shot, given that the scene ought to contain dialogue? One interpretation of this innermost level of reality in H Story (the movie being shot within the fake 'making of' that comprises Suwa's film) suggests that this change affects the other, outer levels: given that the most basic memory has failed (in Dalle), the words of the script for Hiroshima mon amour, none of the other memories represented in Resnais's film may be enacted here; and, as a result, the re-make itself is cut short.

Suwa shoots another attempt to film a scene from Hiroshima mon amour, the scene in which the leading characters bid farewell to one another. This is followed by two brief, silent sequences: Dalle walks along a street in Hiroshima, before running into Machida in another bar, a scene that bears a closer formal resemblance to the scene between Elle and the unknown Japanese man in Hiroshima mon amour. Here; however, there is no indication that this is a filmed scene-no sound of the clapperboard, no noise of crew members issuing orders-and it ends as abruptly as it began. Immediately after, Suwa appears in a mocked-up 'making of' sequence in which he is seen taking the decision to call time on the shoot. Thus, this second scene in a bar between Dalle and Machida marks a moment of crisis across the levels of reality in H Story: the scene is, or may be, at one and the same time, part of a remake of Hiroshima mon amour, part of the 'making of' of a remake of Hiroshima mon amour, and/or part of a film called $H$ Story edited together from the rushes of a 'making of' of a remake of Hiroshima mon amour. The echo of the original fades, but not wholly to black or to silence. In the end, Suwa frames his film around two contrary sources of power: Duras's script and the desire to escape embodied by Dalle in H Story. To quote Suwa himself, "In H Story, the reality named Béatrice resists (hi)story" (Burdeau 2006, p. 90). Dalle's forgetfulness subverts the text; her desire diverts the plot of the love story; and her new-found freedom seems to wrest control of the images that comprise the film.

Several details illustrate Dalle's embodiment of control in the film. Near the beginning of the film she refers to the opening scripted by Duras as "problematic": "There was archive footage," she says, to which Suwa replies, "We have none of that kind of thing." The film later contradicts its own director when, after one of her several flights from the shoot, a shot of Dalle drinking alone (Figure 4a) is followed by a sequence of archive images (windows, a sluicegate, rusty scaffolding) that gesture towards the destruction wrought by the bomb. Once again, this move both is and is not a departure: "ownership" of these images is attributed to Dalle on the basis of her desire to include archive footage and through the way the scene is edited together, but at the same time their inclusion is an echo of Hiroshima mon amour. In Resnais's film, Elle's recollections were shaped in line with a similar formal strategy: the shots of Emmanuelle Riva drinking are followed by images of her memories of Nevers (that is, the juxtaposition of the protagonist in the primary frame with shots from a different time-frame implies the latter belongs to the former). At the same time, however, Dalle's investment in these images does not mean that they are wholly hers: the fleeting frame-detail of an old American clapperboard (Figure $4 \mathrm{~b}$ ), an instant in the archive footage, likewise implies that they pertain to the remake, by recalling the sound of clapperboard Suwa uses in H Story to punctuate the cuts in the fake 'making of' sequences. Thus, the elusive temporality of Hiroshima mon amour becomes an elusive ownership of memory in H Story. 


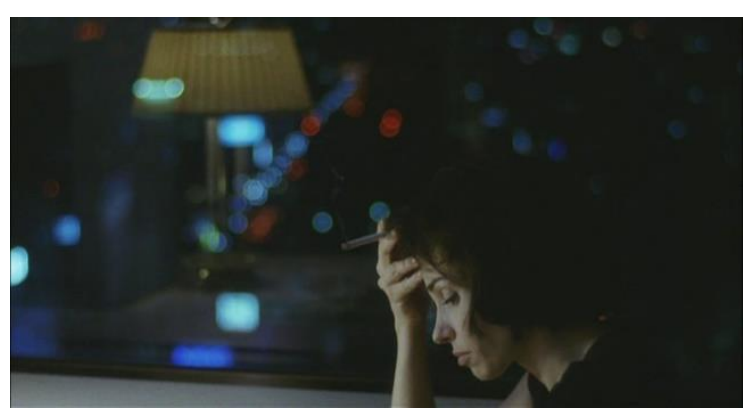

(a)

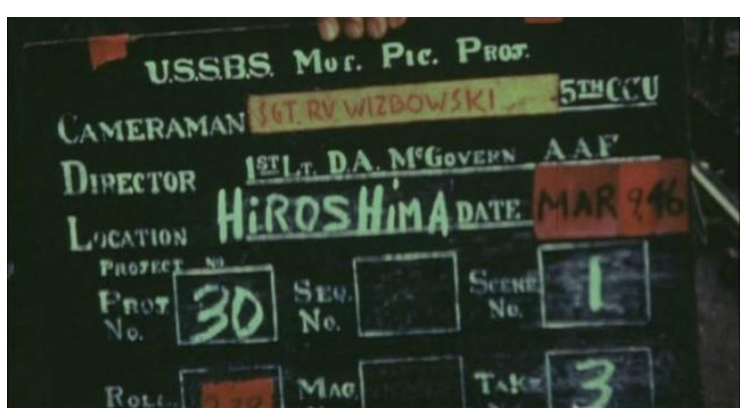

(b)

Figure 4. Frames from H Story. A shot of Béatrice Dalle drinking alone (a) is followed by a sequence of archive images from the Hiroshima bombings (b). Source: DVD edition by Cinéma Indépendant (France).

Archive images reappear in H Story for a second time towards the end of the film, when the decision to close down the shoot has been taken. In this instance, the images do explicitly reference the bombing of Hiroshima: they comprise a panoramic view of the ruins of the recently bombed city (Figure 5a). The scene is followed by a shot of Dalle and Machida walking along various streets in the city (Figure 5b), where it is clear that their walk is separate from the remake and the mocked-up 'making of'. What has happened before this sequence of shots? Through his complex mise en abyme, Suwa has called into question the very possibility of drafting a fiction around Hiroshima. Neither Hiroshima mon amour nor his projected remake can be anything more than a fixed part (literally, a still image) of the "discourse of Hiroshima", which amounts to a further barrier between the actual events (the bombing of the city) and the present.

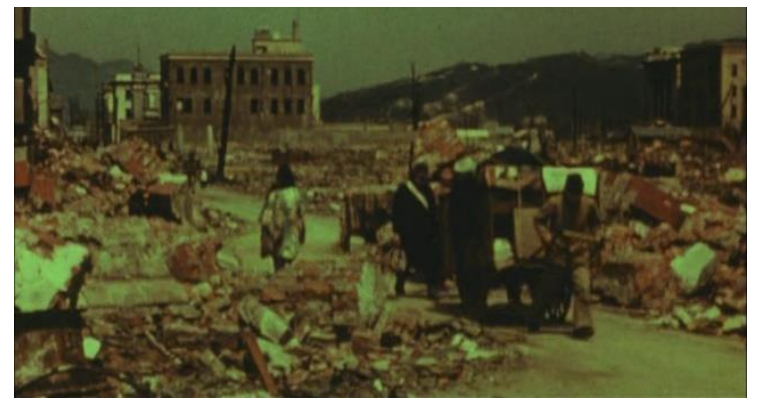

(a)

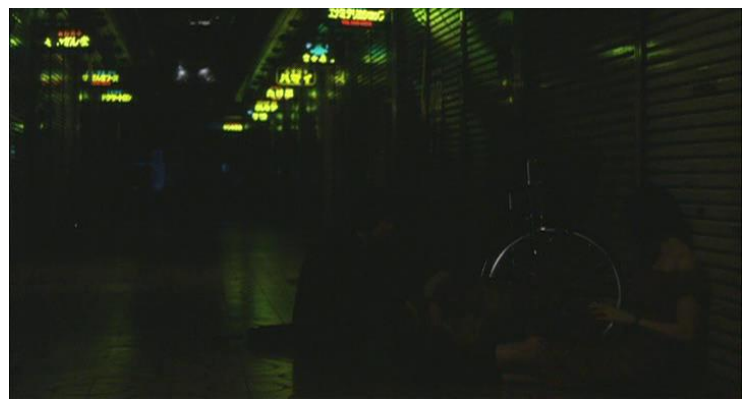

(b)

Figure 5. Frames from H Story. A panoramic view of the ruins of the recently bombed Hiroshima (a) followed by a shot of Dalle and Machida walking along the city in present $(\mathbf{b})$. Source: DVD edition by Cinéma Indépendant (France).

When at last the historical past and the cinematic present are (re)presented in their "pure" form, by means of direct archive footage and an image of the present abstracted from the fictional narrative, the relationship can do nothing other than reflect the unbridgeable distance between them. The past exists as a play of echoes and shadows that tell a new story in the present Hiroshima through which Dalle and Machida move (Verevis 2012, p. 172): their autonomy as a story is effected only through the experience and subsequent flight from such echoes (Duras's script, the museum about the bombing that both visit halfway through the movie). This endorsement of the opening present circles back to the starting point ("It is impossible to talk about Hiroshima") and discloses what Suwa envisions as the heart of his film:

Within the film, the present marks the point when the past becomes the future. This present is in the middle of a story that is History itself. I think that H Story is film in search of a present moment capable of escaping both the past and the future. (Burdeau 2006, p. 90) 


\section{Reconstruction: A Perfect Couple}

Following his experience as a co-producer of H Story, Suwa went on to further his career as a transnational filmmaker by undertaking his first project in Europe. A Perfect Couple was an Arte France initiative with secondary support from a Japanese enterprise (it was coproduced by the company Bitter End), filmed in French on location in Paris. For Suwa, the film also marked a return to the subject-matter and themes of his first two feature-length productions: the couple in crisis. The move from $H$ Story to A Perfect Couple seems to have been a logical one:

Assuming that Hiroshima mon amour (1959) walks the blurred line between fiction and cinematic essay, between literary construct and documentary, between the present time and the time of memory, we may conclude that the film suggests a reading whose scope ranges beyond its historical moment and whose vestiges may be traced to contemporary cinema. Suwa's attempt at an impossible remake leads inevitably to the aesthetic achievements accomplished in A Perfect Couple. (Quintana 2007, p. 54)

Not only is H Story the most explicit account of Suwa's engagement with European modernism, it is also the film that most fully deconstructs his attachment to modernist formal strategies, which according to Quintana involve, "heavily weighting the significance of the frame, the surfaces and volumes that arise within the image, the sounds that cross the visual space and signal certain positions beyond the limits of the space" (Quintana 2007, p. 56), issues that stem from a fundamental rejection of the mode of editing. In A Perfect Couple, comprising only about forty shots in total, Suwa continues his exploration of modernist formal techniques by setting his work in intertextual dialogue with one of the films that had done most to canonize them: Journey to Italy, the cornerstone of European cinematic modernism in both theory and practice.

The intertextual relationship between Journey to Italy and A Perfect Couple is one of allusion; in this instance, Suwa's work is not structured via the disruption of levels of time, space or reality. The main parallels comprise similarities in plot development. Suwa's film also tells the story of a couple who, after a long relationship, are thrown into a crisis that is intensified by a journey: Marie (Valeria Bruni Tedeschi) and Nicolas (Bruno Todeschini) travel from Lisbon to Paris (a city they had left a long time before) to attend the wedding of one of their best friends. The shifts in the story between the arguments shot in interior (the same gloomy hotel room) and the separate escapades of both spouses, as well as the 'miraculous' reconciliation at the end, clearly recall Journey to Italy, as do the kind of escapades each engages in: like the character of George Sanders, Nicolas flirts with the possibility of a fleeting love affair, while Marie, like Ingrid Bergman, endeavors to escape herself by contemplating sculptures (the Rodin Museum in Paris takes the place of the National Archeological Museum in Naples). Suwa himself has acknowledged his deliberate purpose to set A Perfect Couple and Rosellini's film in conversation with one another, especially in developing the character played by Bruni Tedeschi; however, he also noted a key difference to H Story: "A Perfect Couple is not a film that presents resistance to a (hi)story" (Burdeau 2006, p. 90).

An exploration of the meanings that accrue to the statues in the scenes played out by Marie in her visit to the Rodin Museum, in comparison to the parallel experiences of Catherine (the character played by Ingrid Bergman in Journey to Italy) at the National Archeological Museum in Naples, discloses the aesthetic discoveries Suwa made through the practice of intertextualization. In Catherine's first such scene, her engagement with the statues comprises, above all, a present encounter with the past. Following the anodyne commentary of the museum guide, the camera movement implies a continuum of experience between Catherine and the statues by panning along the faces of some of them, before coming to a stop on the main figures: a shared emotional present is generated between the art-works and the character. Subsequent frames are close-ups of the statues' faces, presented from Catherine's subjective viewpoint: the first tracking shot that closes in on a discus thrower whose painted eyes appear to stare directly into the camera lens (Figure 6a) is preceded by a similar camera movement that indicates where Catherine's view is directed (Figure 6b). In the next scene, Catherine herself puts 
her experience into words: "To think that those men lived thousands of years ago ... And you feel like they're just like the men of today. It is as if Nero or Caracalla, Caesar or Tiberius would suddenly tell you what they felt". In marked contrast to the "ascetic" experience described in the poems written by a former lover that had prompted her visit to the museum, Catherine's encounter with the statues is a very earthly experience.

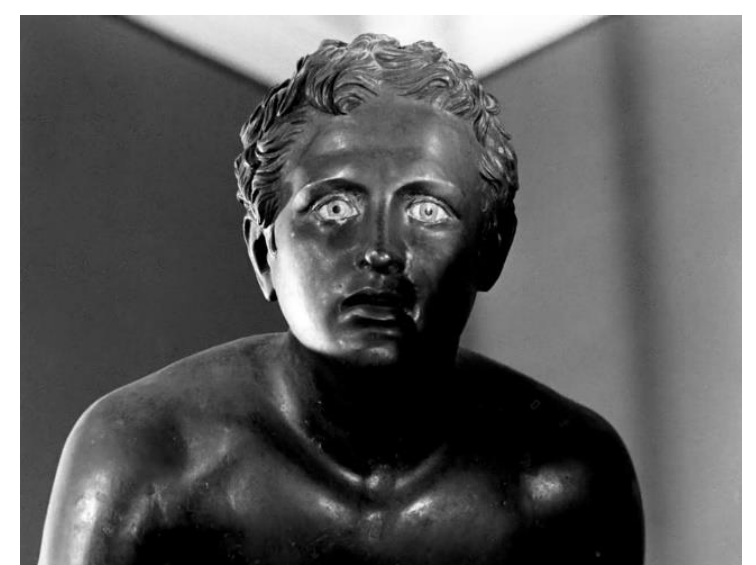

(a)

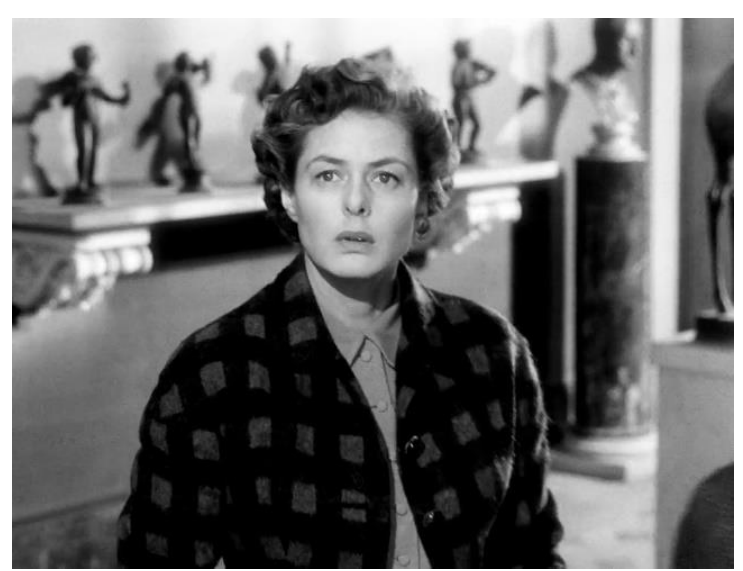

(b)

Figure 6. Frames from Journey to Italy. A tracking shot that closes in on a discus thrower whose painted eyes appear to stare directly into the camera lens (a), preceded by a similar camera movement that indicates where Ingrid Bergman view is directed (b). Source: Blu-Ray edition by The Criterion Collection (USA).

In her perception of Rodin's statues, Marie sees a reflection of her experience of married life. The size of the joined hands (Mains jointes), the nude study of a man worshipping his wife (L'eternelle idole) and an unfinished Eve (Eve) tell of the progress of passion from first love to motherhood, to the final step when the guide's comments redefine Eve by stripping her of her mythic aura: the statue was modelled on a young woman, and was left unfinished when Rodin learned that she was pregnant. Marie's self-projection onto the meanings of the statues takes the place of the dialogue enacted by Catherine. As Neyrat (2006, p. 13) avers, the lines by Rilke about the L'eternelle idole quoted by the museum guide in this scene ("Something of the mood of a purgatory lives in this work. A heaven is near, but not yet attained; a hell is near, and not yet forgotten") may well encapsulate the situation in which the film's protagonists find themselves: a kind of purgatory (the dim interior of their hotel room) that may lead to either separation or reconciliation. The shot of L'eternelle idole depicts the connection between Marie and the statues in an explicit way: the sculpture is shown through its glass case, in whose surface Marie's reflection is clearly seen (Figure 7a). The play of reflections is amplified by a mirror located behind the statue, leading to a confused profusion of images: the image itself, its reflection in the glass case and its reflection in the mirror. In contrast to the direct, close-up shot of Catherine before the statue of the discus thrower, Suwa decides to represent visually the dispersive fragmentation of possible meanings around the statues. At the same time, however, Suwa does also draw on the direct shot of his main character to represent her personal experience of the art-works (Figure 7b). However, a strategy that is worked more subtly in Rosellini's hands takes on a much more cutting form in the representation of Marie's interior life. First, because the close-up is used only very exceptionally in a film structured though long, wide shots; and second, because her facial features are presented in a stylized way: the shot is long, filmed with a handheld camera (unlike the rest of the film, shot with a fixed camera) and tracks more intensely on Marie's face, who weeps as she contemplates the statue of Eve. 


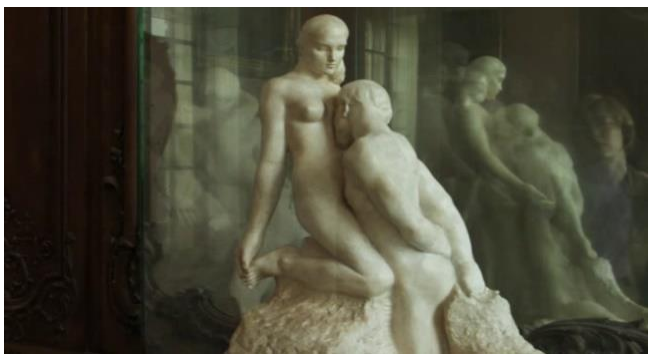

(a)

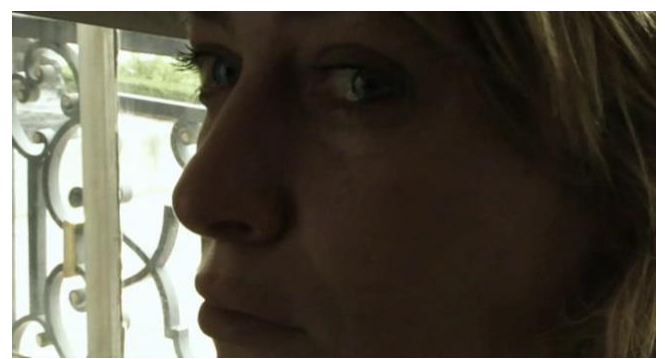

(b)

Figure 7. Frames from A Perfect Couple. A shot of Rodin's L'eternelle idole in which the sculpture is shown through its glass case, in whose surface Valeria Bruni Tedeschi's reflection is clearly seen (a), and an extreme close-up that represents her personal experience of the art-works (b). Source: DVD edition by Intermedio (Spain).

In a later scene, Marie is shown trying to explain her encounter with the statues to her husband. In contrast to Catherine's decision not to refer to the poems written by her former lover to account for her experience, Marie sets out to read aloud to Nicolas from a poem by Rilke about Rodin. Although Marie's personal investment in the visit to the museum has run deeper within her, what she discovers through that experience leads to a development of her character that mirrors Catherine's: the sense of thwarted motherhood. The story about the pregnant model for the statue of Eve, which seems to be the reason Marie weeps in the close-up on her tears, echoes a series of subtle signs about motherhood with which Suwa has seeded his film, leading to the revelation of Marie's unfulfilled desire to be a mother.

A similar story is told about Catherine and revealed in her wanderings (the number of pregnant women she sees on the streets of Naples, for instance). In both Journey to Italy and A Perfect Couple, these sub-plots concerning hidden desire lead to a second encounter with sculptures on each main character's part. In Journey to Italy, the second experience takes place at the site of the excavations in Pompeii rather than the National Archeological Museum in Naples. Catherine witnesses the discovery of the traces of two bodies from the Roman period which had been buried under the lava of Vesuvius. This sculpture is made in the real time of its discovery. The archeologists make a set of holes in the fossilized lava, into the space shaped by the bodies of the dead before they decomposed, which they then fill with plaster. The dried plaster takes the form and position of the bodies at the time of their death. When the archeologists dig out the plaster-sculpture, they discover it represents a couple: "Probably husband and wife. They died together," says one of the archeologists. Rosellini shows the recently revealed plaster statue (Figure 8a), followed by a counter shot-a framed medium shot-of Catherine, her husband and the archaeologist looking at it (Figure 8b). She abruptly exits the scene, weeping at the sight of the sculpture. Rosellini included her reaction, within the same scene, counterpointed by the calm with which the two men contemplate the discovery.

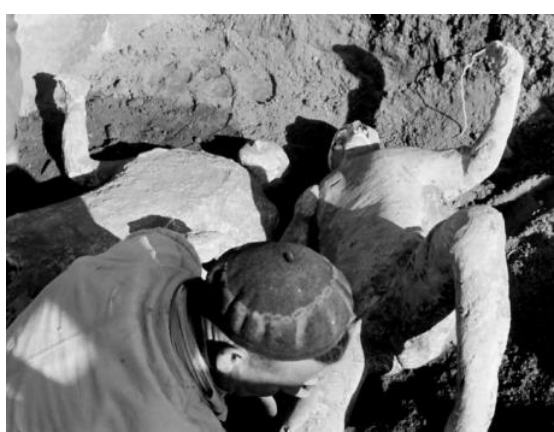

(a)

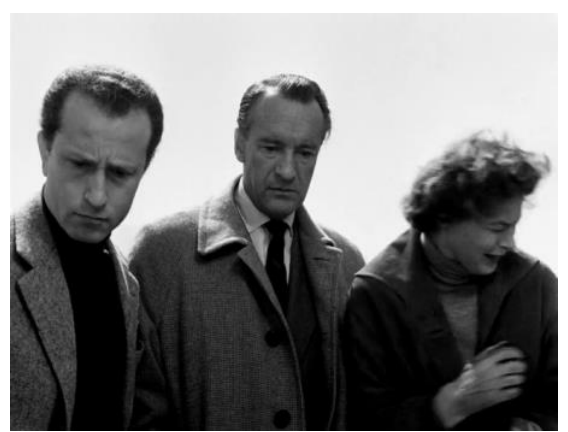

(b)

Figure 8. Frames from Journey to Italy. A revealed plaster statue representing a man and a woman who died in Pompeii (a), followed by a counter shot of the three characters looking at it (b). Source: Blu-Ray edition by The Criterion Collection (USA). 
In this regard, Catherine's reaction to the sculpture uncovered at Pompeii mirrors Marie's experience in the museum more closely; the sudden cry of grief is not a shared experiential present with the statue: it is a deeply personal moment unleashed within the character. Catherine's doomed marriage and unfulfilled desire to be a mother are laid bare by the discovery of the statue. Like Rodin's L'eternelle idole, the statue at Pompeii may be read as an exalted epitome of the act of love. At the same time, however, as with the statue of Eve, unexpected life events (pregnancy, death) may be traced in the material imperfection of the art-works (Rodin's sculpture is unfinished, the Pompeii statue is cast from plaster). The unlikely combination of the exalted and the accidental prompts a visceral reaction in both Catherine and Marie. The mirroring of meanings between the two scenes is underscored by the scene in which Marie encounters the statutes again, on a second visit to the Rodin Museum. On this occasion, the sculptural is transcended by the real: while looking at the statue of Eve, Marie meets a former boyfriend from high school, who is visiting the museum with his son. Suwa repeats the sequence of shots: a general shot of Marie contemplating the statue is followed by a tight close-up of her face from a hand-held camera, as the conversation with her former boyfriend begins (Figure 9a). Their conversation extends into a wide shot that encompasses Marie, the man and his son (Figure 9b). They reminisce with one another until the man reveals that his wife, the boy's mother, had died years before. Marie is deeply moved by this revelation, just as she was by her contemplation of the statue of Eve earlier. This further sign of her own frustrated desire to be a mother is intensified by the sense of a loving union—an apparently loving marriage—cut short by the woman's death.

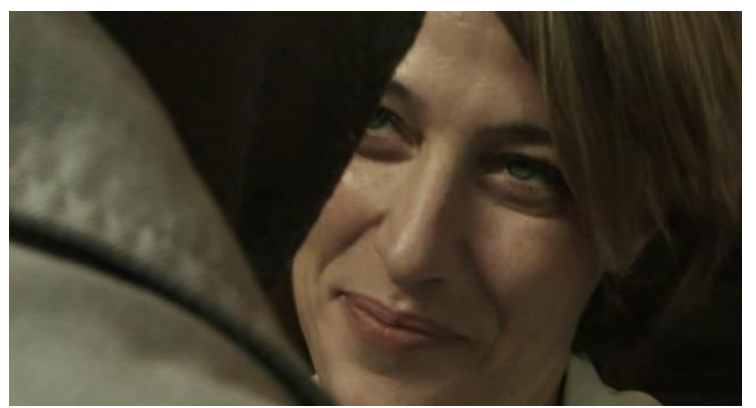

(a)

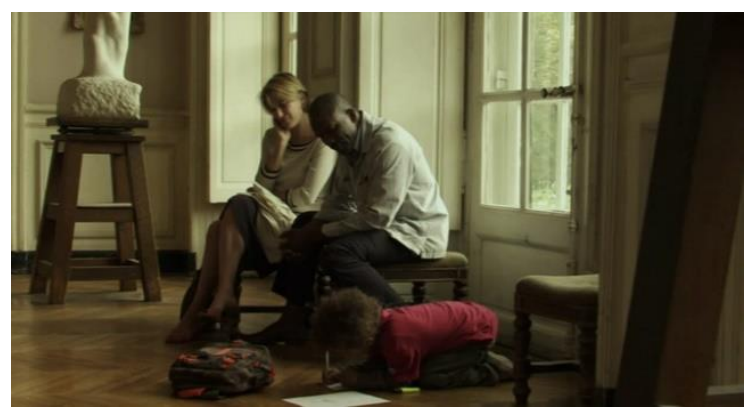

(b)

Figure 9. Frames from A Perfect Couple. A tight close-up of Valeria Bruni Tedeschi's face from a hand-held camera (a), followed by a wide shot that encompasses her whole conversation (b). Source: DVD edition by Intermedio (Spain).

The story told in the Rodin Museum parallels the experience of the plaster statue in Journey to Italy. In both films the sculpture motif is carried across two scenes: in the first, creating a moment of shock, before moving on, in the second, to yield an epiphany. Suwa illustrates this progression in more visual terms: while the tight close-up was the climax of the first scene set in the museum, it is deployed in the second scene just before the moment when Marie catches sight of the man and his son. The first, climactic close-up creates a greater emotional impact; whereas the effect of the second close-up is more intimate and calmer. The exact meaning of Catherine's reaction to the plaster statue and Marie's response to seeing the man and his son remains unexplained (beyond a general idea of the desire for fulfilled love and motherhood), but it is clear that they set up the common ending to their respective stories, both of which come to a close on a miraculous reconciliation with their husbands. These endings are miraculous in that no logical line can be drawn from the external moments of revelation shown on screen and the reaffirmation of love at the end. The cut from one instant to the next is, once more, incommensurable.

\section{Conclusions}

The mise en abyme evinced in H Story is shaped by its intertextual relationship with Hiroshima mon amour via a series of direct references. The several levels of this mise en abyme mirror the 
corresponding levels in Resnais's film, which in turn render the earlier work itself a further layer in the film-within-a-film. By contrast, the intertextual relationship between A Perfect Couple and Journey to Italy is generated through allusion. Rosellini's original move towards mise en abyme comprises a reconfiguration of the meaning of the story by drawing a preceding narrative articulated by the statues into the diegetic frame of his work. Suwa replicates this strategy through the similarity in motif (the statues), the meanings that accrue to it (human love and motherhood) and the outline of the plot; at the same time, Suwa strips away the stylistic features Rosellini favors (he does not use the shot/counter-shot approach, instead tending towards the long fixed shot which highlights the vastness of the frame) and pushes the bounds of the representational power of the images he uses (Suwa uses other devices such as the play of reflections and mirrors in several shots, in addition to the mise en abyme enacted by the sculptures). Not only does Suwa's act of deconstruction in H Story evince how far Hiroshima lies beyond representation, but it also identifies the formal strategies deployed in Hiroshima mon amour to assert its aesthetic reality. A film like $A$ Perfect Couple springs from a similar assertion, the realization of such formal goals. Suwa lays no claim to the national sovereignty of particular discourses (envisioning Hiroshima from the perspective of Japan, for instance); his aim seems be to enter a pure, European-centered cinematic tradition so as to apply its formal achievements in even more stringent ways. Thus, Suwa's break through European borders by extending and radicalizing the forms of its cinematographic modernism seems no more than an accidental side-effect of his close belonging to the European way of framing cinema.

Funding: This research received no external funding.

Acknowledgments: This research was made possible with the support of the Department of Audiovisual Culture and Communication and the Friends Association of the University of Navarra.

Conflicts of Interest: The author declares no conflict of interest.

\section{References}

Armes, Roy. 1968. The Cinema of Alain Resnais. London: Zwemmer.

Bazin, André. 2005. What Is Cinema? Berkeley: University of California Press.

Burdeau, Emmanuel. 2006. Nobuhiro Suwa: “Mes Films Ne Cherchent Pas À Conclure”. Cahiers Du Cinéma 610: 87-90.

Dällenbach, Lucien. 1989. The Mirror in the Text. Chicago: University of Chicago Press.

Daney, Serge. 1983. La Rampe. Cahier Critique 1970-1982. Paris: Cahiers du cinéma/Gallimard.

Deleuze, Gilles. 1989. Cinema 2. The Time-Image. Minneapolis: University of Minnesota Press.

Font, Domènec. 2012. Cuerpo a Cuerpo: Radiografías Del Cine Contemporáneo. Barcelona: Galaxia Gutenberg.

Fraga, Xesús. 2018. Nobuhiro Suwa: Las Imágenes Son La Huella de Lo Real Pero, Al Mismo Tiempo, Son Ilusiones. La Voz de Galicia, April 25. Available online: https:/ / www.lavozdegalicia.es/noticia/cultura/ 2018/04/25/imagenes-huella-real-tiempo-ilusiones/0003_201804G25P32991.htm (accessed on 15 July 2018).

Genette, Gérard. 1997. Palimpsests. Literature in the Second Degree. Lincoln: University of Nebraska Press.

Grange, Marie-Françoise. 2011. Le Film Pour Mémoire: Sur H Story (Nobuhiro Suwa, 2000). Cinemas-Revue d'Études Cinematographiques/Journal of Film Studies 21: 171-83. [CrossRef]

Hainge, Greg. 2008. A Tale of (at Least) Two Hiroshimas: Nobuhiro Suwa's H Story and Alain Resnais's Hiroshima Mon Amour. Contemporary French Civilization 32: 147-173. [CrossRef]

Joyard, Olivier. 2001. Le Printemps À Hiroshima. Cahiers Du Cinéma 561: 68-70.

Neyrat, Cyril. 2006. Marie et Les Statues. Cahiers Du Cinéma 609: 12-14.

Quintana, Àngel. 2007. La Modernidad Europea En El Cine Asiático: Reflexiones Sobre Una Migración Estética. In Derivas Del Cine Europeo Contemporáneo. Edited by Domènec Font and Carlos Losilla. Valencia: Ediciones de la Filmoteca, pp. 53-68.

Rivette, Jacques. 1955. Lettre Sur Rossellini. Cahiers Du Cinéma 46: 14-24.

Stam, Robert, Robert Burgoyne, and Sandy Flitterman-Lewis. 2005. New Vocabularies in Film Semiotics. Structuralism, Post-Structuralism and Beyond. London and New York: Routledge. 
Tesson, Charles. 2001. Rencontre/Nobuhiro Suwa. Cahiers Du Cinéma 561: 70-72.

Verevis, Constantine. 2012. A Personal Matter: H Story. In Film Remakes, Adaptations and Fan Productions. London: Palgrave Macmillan, pp. 159-175. (CC BY) license (http://creativecommons.org/licenses/by/4.0/). 